\title{
Assessment of Quality of Azithromycin, a Macrolide Antibiotic by NMR Spectroscopy
}

\author{
Mohammad Shoeb, Md. Farhanul Alam, Md. Mazharul Islam, Nargis Parvin, \\ Md. Nazrul Islam and Md. Iqbal Rouf Mamun
}

Department of Chemistry, University of Dhaka, Dhaka-1000, Bangladesh

(Received: November 14, 2020; Accepted: December 30, 2020; Published (web): January 28, 2021)

\begin{abstract}
A total of forty five pharmaceutical tablets containing $500 \mathrm{mg}$ azithromycin from 9 (nine) different companies were collected from local pharmacies and evaluated the quality of the antibiotics with standard azithromycin by physical, chromatographic (HPLC), Fourier Transform Infrared (FT-IR), and ${ }^{1} \mathrm{H} \&{ }^{13} \mathrm{C}$ Nuclear Magnetic Resonance (NMR) spectroscopic studies. Weight variation of all tested tablets were within $0.1-1.8 \%$ which is in the allowed variation of 5\%. Two prominent absorption bands were observed at 1723 and $1187 \mathrm{~cm}^{-1}$ in the FT-IR spectrum of all samples and standard for the presence of $>\mathrm{C}=\mathrm{O}$ and $-\mathrm{C}-\mathrm{O}$ groups, respectively due to the macrocyclic lactone ring. HPLC coupled with PDA detector (at 210 and $215 \mathrm{~nm}$ ) gave reproducible results at retention time of $10.5 \mathrm{~min}$ for standard and samples. The ${ }^{1} \mathrm{H}$ and ${ }^{13} \mathrm{C}$ NMR spectral data of the standard azithromycin and test samples were found to be identical which led to the conclusion that ${ }^{1} \mathrm{H}$ - and ${ }^{13} \mathrm{C}-\mathrm{NMR}$ experiments are feasible tools for qualitative determination of azithromycin in tablets. All the described methods determined the quality of analyzed tablets well.
\end{abstract}

Key words: Pharmaceuticals Drug, Antibiotics, Azithromycin, FT-IR, HPLC, ${ }^{1} \mathrm{H}$ NMR, ${ }^{13} \mathrm{C}$ NMR

\section{Introduction}

Antibiotics are the substance produced by microorganisms from different sources and are used in very low concentration to inhibit the reproduction, growth or destroy other microorganism (Trigathi, 2003). Among the most agile therapeutic drugs, antibiotics which antagonize both the bacterial growth and reproduction and they are classified according to their mode of action such as antibiotics those prevent the bacterial cell wall synthesis, antibiotics those prevent the protein synthesis and some antibiotics those inhibit the DNA synthesis for their survival (Jumaa and Karama, 2015). In medical science, the discoveries of antibiotics are very important for the treatment of various bacterial infections in community to individual patient health risk (Godfrey et al., 2014). Azithromycin is one of the antibiotic of macrolide group, due to the presence of large macrolide ring, which prevent the bacterial cells from synthesizing necessary protein for their survival and initially used against infections caused by respiratory pathogens (Al-Rimawi and Kharoaf, 2010). This $2^{\text {nd }}$ generation macrolide antibiotic drug is used broadly to cure infectious diseases caused by bacteria (Azithromycin, 2015; Firth and Prathapan, 2020) in respiratory tract, sexually transmitted diseases or soft tissue infections due to its excellent antibacterial activity and pharmacokinetics (Li et al., 2011). Piva, a pharmaceutical company discovered the drug in 1980, and it was approved in 1988 (Greenwood and David, 2008; Alapi and Fischer, 2006). Now it is in the list of essential medicines of the World Health Organization (WHO, 2019). WHO published the model list of essential medicines that

Corresponding author: Mohammad Shoeb; Email: shoeb71@ yahoo.com

DOI: https://doi.org/10.3329/bpj.v24i1.51634 
contains the safest and most effective medications to meet the important needs in health care systems. The list is frequently used by countries to help in the development of their own local lists of essential medicine (Essential Medicine, 2017). It is considered as a critically important pharmaceutical drug by WHO for human health risk (WHO, 2018) and sold globally under different commercial name (Azithromycin International Brand, 2017). Azithromycin, generally administered in tablet formulation, is one of the best-sold pharmaceutical drugs in the world, and structurally its lactone ring is 15 -membered. Chemically, it is $(2 \mathrm{R}, 3 \mathrm{~S}, 4 \mathrm{R}, 5 \mathrm{R}, 8 \mathrm{R}$, $10 \mathrm{R}, 11 \mathrm{R}, 12 \mathrm{~S}, 13 \mathrm{~S}, 14 \mathrm{R})$-2-ethyl-3,4,10-trihydroxy3,5,6,8,10,12,14-heptamethyl-15-oxo-11-

$\{[3,4,6$ trideoxy-3 (dimethylamino)- $\beta$-D-xylo-]oxy $\}$ 1-oxa-6-azacyclopentadec-13-yl 2,6-dideoxy-3-Cmethyl-3-O-methyl- $\alpha$-L-ribo-hexopyranoside, a semi synthetic macrolide antibiotic (Jayanna et al., 2012). The mechanism of action of this drug is bacteriostatic and bactericidal by the transportation of macrolides, accumulating within leukocytes, to the target infectious site. Since it binds to the 50-S subunit of the bacterial ribosome, the inhibition of mRNA translation and nucleic acid synthesis are not affected (Rang et al., 2003; FDA, 2016). Recently, being used in research along with other pharmaceutical drugs for the COVID-19 medication purpose (Gautret et al., 2020; McCreary and Pogue, 2020). There are several methods such as UV-visible spectrophotometry, chromatography, ${ }^{1} \mathrm{H}$ and ${ }^{13} \mathrm{C}$ NMR Spectroscopy which are widely used for the qualitative and quantitative analyses of pharmaceutical drugs (Bekele and Gebeyehu, 2012). Fourier Transform Infrared (FT-IR), a vibrational spectroscopic methods, is also used (Ji et al., 2011) widely in pharmaceutical company because of its satisfaction and reliable efficiency in that purpose (Gendrin et al., 2008, Scafi and Pasquini, 2001). High performance liquid chromatography (HPLC) (Shaikh et al., 2008; Yang et al., 2009) with ultraviolet or photodiode array detector can be used for the analysis of azithromycin in bulk sample. This method is also applicable for the analysis of azithromycin in bulky powder of different dosage forms. Usually, the wavelength of $210 \mathrm{~nm}$ and $215 \mathrm{~nm}$ are the two chosen wavelengths for monitoring azithromycin in optimized conditions which provides better precision and accurate information (Zubata et al., 2002).

This paper evaluates the quality of azithromycin tablets available in local market with standard azithromycin by physical, chromatographic method and ${ }^{1} \mathrm{H}$ - and ${ }^{13} \mathrm{C}-\mathrm{NMR}$ spectroscopic studies.

\section{Materials and Methods}

Sample collection: Azithromycin tablets of nine different pharmaceutical companies were purchased from local pharmacies in Dhaka city. The collected samples were coded as shown in Table 1. Tablet shapes were caplet like with $500 \mathrm{mg}$ of active ingredient.

Chemicals and reagents: Different organic and inorganic chemicals and reagents were used during the research work such as $\mathrm{Na}_{2} \mathrm{HPO}_{4}$ (Scharlab S.L., Sentmenat, Spain), Silica sand (Kanto Chemical Co. Inc.), Ethanol (Merck KGaA, Darmstadt, Germany), $n$-Hexane (RCI Labscan Limited, USA), Methanol (Merck KGaA, Darmstadt, Germany), Concentrated $\mathrm{H}_{3} \mathrm{PO}_{4}$ (Merck KGaA, Darmstadt, Germany), Acetone (Sigma-Aldrich), HPLC grade acetonitrile (Sigma-Aldrich), Dichloromethane (RCI Labscan Limited, USA), Dimethyl sulfoxide (RCI Labscan Limited, USA) and Azithromycin standard.

Evaluation of weight variation: The tablets of each manufacturer were weighed individually and average weight of tablet was determined. The percentage of weight variation was also calculated by following equation.

Percentage of weight variance $=$ $\frac{\text { Individual weight-Average weight }}{\text { Average weight }} \times 100 \%$

IR spectroscopic profiling: The IR-spectra of all samples were recorded on a Shimadzu Fourier Transformation Infrared spectrophotometer over a range of $400-4000 \mathrm{~cm}^{-1}$. $\mathrm{KBr}$ was used as background. The diffuse reflectance method was implemented. In this method, a few mg of sample were taken with equivalent amount of $\mathrm{KBr}$ and ground in a mortar with a pestle to pressurize into a 
pellet. The $\mathrm{KBr}$ pellet was taken in a reflectance cell and their spectrum was recorded.

HPLC analysis: Standard stock solution of 1500 $\mu \mathrm{g} / \mathrm{mL}$ was prepared by taking $15 \mathrm{mg}$ of standard azithromycin in $10.0 \mathrm{~mL}$ volumetric flask and adding the diluents HPLC grade acetonitrile and deionized water in 40:60 (v/v). Serial dilutions were made to get solutions of different concentrations. The powdered sample $(10 \mathrm{mg})$ was taken into a $10.0 \mathrm{ml}$ volumetric flask and diluted with $10.0 \mathrm{ml}$ of the prepared diluents and sonicated for $20 \mathrm{~min}$. Then, the solution was filtered through $0.45 \mu \mathrm{m}$ nylon filter into HPLC vials. A phosphate buffer solution of $0.03 \mathrm{M}$ was made for the mobile phase using $\mathrm{Na}_{2} \mathrm{HPO}_{4}$. The mobile phase was 50:50 mixtures $(\mathrm{v} / \mathrm{v})$ of acetonitrile and buffer. The $\mathrm{pH}$ of the mobile phase was adjusted to 8.0. The samples were analyzed using a Shimadzu HPLC (Shimadzu, Japan) chromatographic system with $\mathrm{C}_{18}$ reversed phase column $(250 \mathrm{~mm} \times 4.6 \mathrm{~mm} ; 5 \mu \mathrm{m})$. All samples were analyzed using an isocratic elution method with the mobile phase at a flow rate of $1.2 \mathrm{~mL} / \mathrm{min}$. The detector was set at 210 and $215 \mathrm{~nm}$ wavelengths and the injection volume was $20 \mu \mathrm{L}$.

Acquisition of NMR spectra: The ${ }^{1} \mathrm{H}-$ and ${ }^{13} \mathrm{C}$ NMR spectra of standard azithromycin and that obtained from tablet samples was recorded on the NMR (Bruker $400 \mathrm{MHz}$ ) instrument.

\section{Results and Discussion}

Weight variation test of the tablets manufactured by different pharmaceuticals was performed and the results are shown in Table 1.

Table 1. Weight variation with relative standard deviations (RSD) of samples.

\begin{tabular}{lcccccccccc}
\hline Sample code & 1 & 2 & 3 & 4 & 5 & 6 & 7 & 8 & 9 \\
\hline \multirow{2}{*}{ Weight (mg) of 5 } & 982 & 808 & 883 & 800 & 697 & 698 & 723 & 758 & 744 \\
tablets from each & 966 & 797 & 886 & 797 & 694 & 691 & 710 & 752 & 732 \\
company & 970 & 807 & 895 & 811 & 689 & 689 & 726 & 760 & 738 \\
& 979 & 812 & 889 & 804 & 700 & 701 & 713 & 750 & 726 \\
\hline Average wt. (mg) & 974 & 805 & 840 & 801 & 696 & 695 & 718 & 755 & 732 \\
\hline & 0.82 & 0.37 & 0.79 & 0.12 & 0.14 & 0.43 & 0.70 & 0.40 & 1.64 \\
Weight variation & 0.10 & 0.12 & 1.01 & 1.25 & 0.86 & 0.14 & 0.28 & 0.13 & 1.78 \\
(\%) of 5 tablets & 0.82 & 0.99 & 0.45 & 0.50 & 0.29 & 0.58 & 1.11 & 0.40 & 0.03 \\
from each & 0.41 & 0.25 & 0.56 & 1.25 & 1.01 & 0.86 & 1.11 & 0.66 & 0.82 \\
company & 0.51 & 0.87 & 0.11 & 0.37 & 0.57 & 0.86 & 0.70 & 0.66 & 0.82 \\
\hline RSD (\%) & 0.60 & 0.62 & 0.70 & 0.84 & 0.66 & 0.64 & 0.84 & 0.49 & 1.20 \\
\hline
\end{tabular}

According to the British Pharmacopoeia (2011), not more than two of the individual tablets weight should deviate from the average mass by more than the allowed percentage deviation whereas none should deviate by double the allowed percentage deviation. Average tablet mass and corresponding percentage deviation allowed is indicated in the Table 2.
Table 2. Allowed relative standard deviation (Sengupta, 1988).

\begin{tabular}{lc}
\hline Average weight $(\mathrm{mg})$ & $\begin{array}{c}\text { Percentage deviation } \\
\text { allowed }(\%)\end{array}$ \\
\hline Less than 80 & 10 \\
Greater than 80 and less & 7.5 \\
than 250 & 5 \\
Greater than 250 & \\
\hline
\end{tabular}


As seen from the Table 1 that the range of the relative standard deviation of the weight of the manufactured tablets is $0.5 \%-1.2 \%$. The average weight was $695-974 \mathrm{mg}$. The amount found in this study is well below the allowed deviation which is $5 \%$. So, the tablets showed very little weight variability.

Table 3. Assignment of IR absorption peaks of standard azithromycin.

\begin{tabular}{llll}
\hline Absorption $\left(\mathrm{cm}^{-1}\right)$ & Intensity & Type of Vibration & Functional Group \\
\hline 3494 & Strong, broad & Stretching & O-H \\
2973 & Strong & Stretching & Methyl C-H \\
1723 & Medium & Stretching & Ester C=O \\
1463 & Medium & Bending & Methylene C-H \\
1379 & Medium & Bending & Methyl C-H \\
1187 & Strong & Stretching & C-O \\
1046 & Strong & Stretching & C-N \\
\hline
\end{tabular}

The IR spectrum of the standard was taken as a reference to assess the IR spectra of the azithromycin tablets and prominent peak assessment is shown in Table 3. The IR spectra were recorded on a Shimadzu FT-IR spectrophotometer over the range of 400-4000 $\mathrm{cm}^{-1}$. All of the IR spectra of nine samples were analyzed and the peaks are the ones that are found in all the sample spectra. Bands related to the axial stretching and bending of $\mathrm{C}-\mathrm{H}$ of the methyl groups, which were located in the region of $2800-3000 \mathrm{~cm}^{-1}$ and $1377 \mathrm{~cm}^{-1}$. The sharp and intense band located at $1723 \mathrm{~cm}^{-1}$, which can be assigned to the axial stretching of the $\mathrm{C}=\mathrm{O}$ group present in the lactone. Other important bands present in the spectrum were observed in the range around $1187 \mathrm{~cm}^{-1}$, which appeared due to the absorption associated to the axial stretching of $\mathrm{C}-\mathrm{O}$. The excipients do not create interference in these regions. So all the tablet can be qualitatively analyzed for azithromycin. Among these characteristic bands, only two of them could be used for quantitative purposes (1723 and $1187 \mathrm{~cm}^{-1}$ ) since they did not overlap with the bands of the other functional groups. Thus, FT-IR spectroscopic technique is a superior way for the qualitative characterization of the antibiotics like azithromycin, a pharmaceutical product, in solid formulations.

All samples and standard were analyzed by HPLC. The main characteristics of the HPLC chromatograms were the retention time of azithromycin which was $10.5 \mathrm{~min}$ at 215 and $210 \mathrm{~nm}$. The peak intensities and areas were found to be increased with the concentration of the standard solution of azithromycin. There is peak asymmetry in the chromatogram and the tailing is clearly observable in these chromatograms. This can be explained due to the basic nature of the azithromycin compound. Similar pattern are usually observed during analysis of basic drugs and in chromatography of pharmaceutical ingredients. These compounds strongly interacting with the polar end of the HPLC column packing materials cause peak asymmetry and leads to lower separation efficiencies. The standard solutions of $300,450,600,750 \mu \mathrm{g} / \mathrm{mL}$ were injected one after another with an interval of solvent/blank injection and data were recorded at 210 and $215 \mathrm{~nm}$. They both provided similar peaks at the retention time of 10.5 minutes (Figure 1).

Chromatograms of all the collected samples were analyzed with the same chromatographic condition as the standard solution and observable peaks were also found at the same retention time as the standard (Figure 2).

NMR spectral data: The ${ }^{1} \mathrm{H}$ and ${ }^{13} \mathrm{C}$ NMR spectral data were used to compare the samples with the standard azithromycin (Figure 3 ). The ${ }^{13} \mathrm{C}$ NMR spectrum of the standard azithromycin revealed the presence of thirty eight carbons with fifteen methine, thirteen methyl, five methylene and four quaternary 
carbons. The signal at $\delta_{\mathrm{C}} 179$ was attributed to the lactone quaternary carbon at position $\mathrm{C}-1$ of the macrolide ring and other three signals of quaternary carbons were observed at 73.7, 73.9 and $73.0 \mathrm{ppm}$, respectively for carbon at 6,12 and 3". Signals at $\delta_{\mathrm{C}}$ $73.7,73.4,73.9,70.8$ and $78.2 \mathrm{ppm}$ were assigned to the carbons $6,11,12,2$ ' and 4" containing hydroxyl group, respectively.

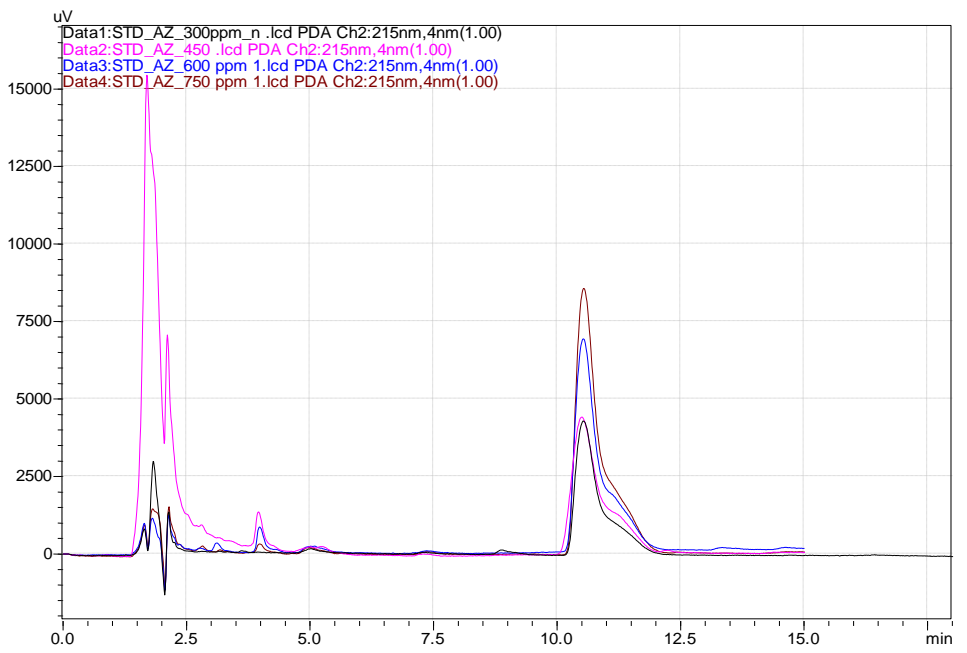

Figure 1. Chromatogram of standard azithromycin of various conc. at $215 \mathrm{~nm}$
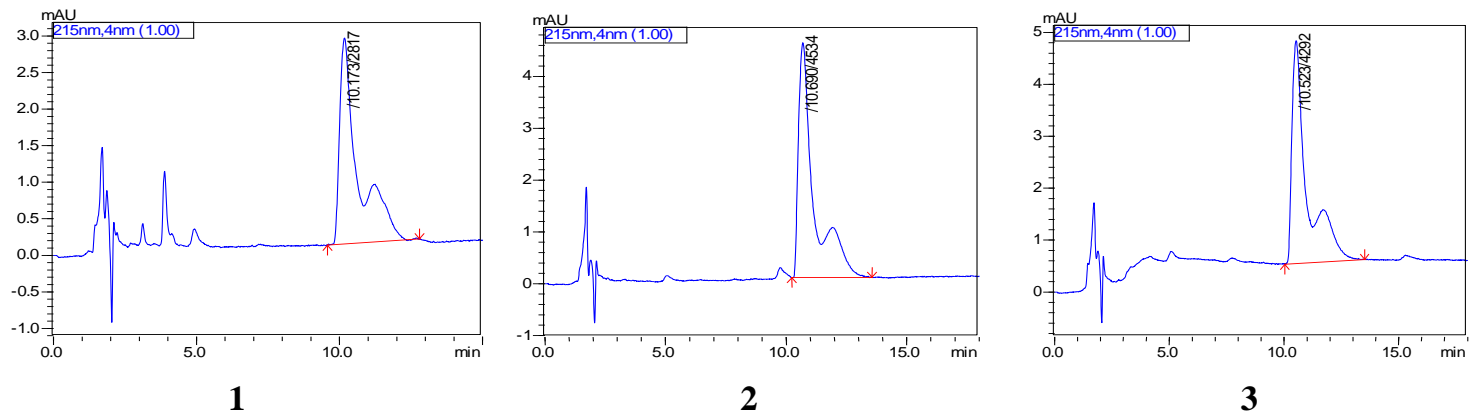

Figure 2. Chromatograms of the first three samples at $215 \mathrm{~nm}$

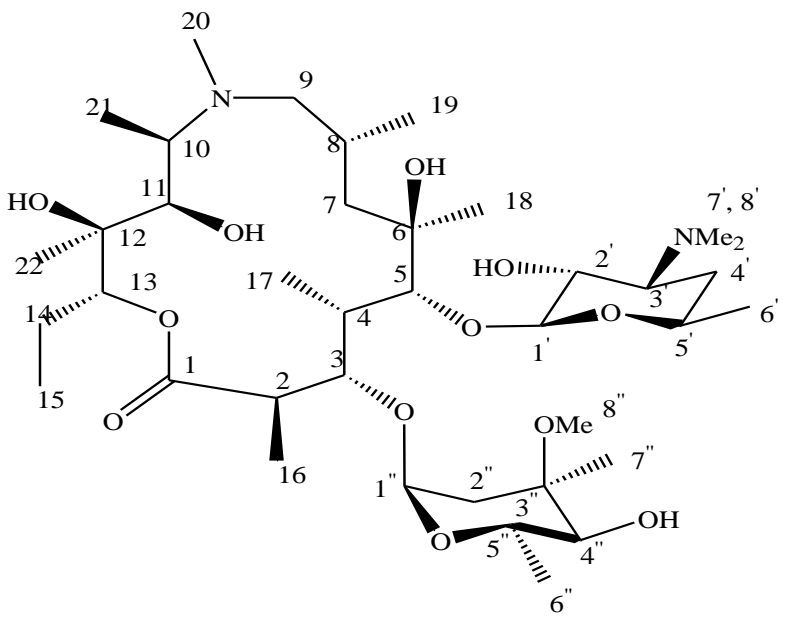

Figure 3. Structure of Azithromycin. 
${ }^{I} H$ NMR spectral data of standard azithromycin (400 MHz, CDCl $\left.l_{3}\right): \delta 0.88(3 \mathrm{H}, \mathrm{t}, J=7.2 \mathrm{~Hz}, \mathrm{H}-15)$, $0.90(3 \mathrm{H}, \mathrm{d}, J=6.0 \mathrm{~Hz}, \mathrm{H}-19), 1.02(3 \mathrm{H}, \mathrm{d}, J=6.2 \mathrm{~Hz}$, H-17), 1.08 (3H, s, H-22), 1.17 (1H, d, J=6.4 Hz, H21), $1.21(3 \mathrm{H}, \mathrm{d}, J=6.0 \mathrm{~Hz}, \mathrm{H}-16), 1.23$ (3H, d, $J=8.0$ Hz, H-6') 1.26 (2H, m, H-7', H-4'), 1.28 (3H, s, H7' '), 1.30 (3H, s, H-6), 1.32 (3H, d, J=8.2 Hz, H-6"), $1.50(1 \mathrm{H}, \mathrm{m}, \mathrm{H}-14), 1.59(1 \mathrm{H}, \mathrm{dd}, J=6.4,7.8 \mathrm{~Hz}, \mathrm{H}-$ 2”), $1.65(1 \mathrm{H}, \mathrm{m}, \mathrm{H}-4$ '), $1.79(1 \mathrm{H}, \mathrm{d}, J=10.0 \mathrm{~Hz}, \mathrm{H}-$ 7), $1.89(1 \mathrm{H}, \mathrm{m}, \mathrm{H}-14), 2.02(1 \mathrm{H}, \mathrm{d}, J=8.5 \mathrm{~Hz}, \mathrm{H}-9)$, $2.16(2 \mathrm{H}, \mathrm{m}, \mathrm{H}-4, \mathrm{H}-8), 2.30(1 \mathrm{H}, \mathrm{d}, J=9.8 \mathrm{~Hz}, \mathrm{H}-4$ " $\mathrm{OH}), 2.32$ (6H, s, H-7'/H-8'), 2.37 (3H, s, H-1), 2.55 (1H, d, H-2'), $2.68(1 \mathrm{H}, \mathrm{s}, \mathrm{H}-3$ '), $2.70(1 \mathrm{H}, \mathrm{d}, \mathrm{H}-9)$, $3.00(1 \mathrm{H}, \mathrm{q}, \mathrm{H}-10), 3.07(1 \mathrm{H}, \mathrm{s}, \mathrm{H}-2), 3.05(1 \mathrm{H}, \mathrm{s}, \mathrm{C}-$ 6-OH), 3.07 (1H, s, H-4'), 3.24 (1H, dd, $J=10.1,7.6$ Hz, H-2'), 3.33 (3H, s, H-8"), 3.35 (1H, m, C-12$\mathrm{OH}), 3.55$ (1H, s, H-5'), 3.61 (1H, d, J=7.8 Hz, H-5), $3.66(1 \mathrm{H}, \mathrm{d}, J=9.0 \mathrm{~Hz}, \mathrm{H}-11), 4.07(1 \mathrm{H}, \mathrm{dq}, \mathrm{H}-5$ '), $4.26(1 \mathrm{H}, \mathrm{dd}, J=8.0,2.0 \mathrm{~Hz}, \mathrm{H}-3), 4.43(1 \mathrm{H}, \mathrm{d}, J=6.8$ $\left.\mathrm{Hz}, \mathrm{H}-1^{\prime}\right), 4.68(1 \mathrm{H}, \mathrm{t}, J=7.0 \mathrm{~Hz}, \mathrm{H}-13), 5.17(1 \mathrm{H}, \mathrm{d}$, $J=5.0 \mathrm{~Hz}, \mathrm{C}-11-\mathrm{OH}), 5.18(1 \mathrm{H}, \mathrm{d}, J=6.0 \mathrm{~Hz}, \mathrm{H}-1$ ”), $9.65(1 \mathrm{H}, \mathrm{s}, \mathrm{C}-6-\mathrm{OH})$.

${ }^{13} \mathrm{C}$ NMR spectra data of standard azithromycin (100 $\mathrm{MHz}, \mathrm{CDCl}_{3}$ ): $\delta$ (ppm) 7.3 (C-21), $9.0(\mathrm{C}-17)$, 11.3 (C-15), 14.5 (C-16), 16.3 (C-22), 18.2 (C-6”), 21.4 (C-14), 21.6 (C-6'), 21.7 (C-19) 22.0 (C-7”), 26.7 (C-8), 27.6 (C-18), 28.1 (C-4'), 34.6 (C-20), 36.2 (C-2”), 40.5 (C-7') 40.5 (C-8'), 42.4 (C-4), 42.5 (C-7), 45.4 (C-2), 49.5 (C-8”), 62.6 (C-10), 65.7 (C5”), 65.9, (C-3'), 68.7 (C-5'), 70.1 (C-9), 70.8 (C-2'), 73.0 (C-3”), 73.4 (C-11), 73.7 (C-6), 73.9 (C-12), 77.5 (C-13), 77.7 (C-3), 78.1 (C-4"), 83.4 (C-5), 94.5 (C-1"), 102.9 (C-1'), 179.0 (C-1).

${ }^{1} \mathrm{H}$ NMR spectral data of sample $1(400 \mathrm{MHz}$, $\left.C D C l_{3}\right): \delta 0.85(3 \mathrm{H}, \mathrm{t}, J=7.2 \mathrm{~Hz}, \mathrm{H}-15), 0.90(3 \mathrm{H}, \mathrm{d}$, $J=6.1 \mathrm{~Hz}, \mathrm{H}-19), 1.02(3 \mathrm{H}, \mathrm{d}, J=6.3 \mathrm{~Hz}, \mathrm{H}-17), 1.09$ (3H, s, H-22), $1.17(1 \mathrm{H}, \mathrm{d}, J=6.2 \mathrm{~Hz}, \mathrm{H}-21), 1.22$ (3H, d, J=6.4, Hz H-16), 1.24 (3H, d, J=7.8 Hz, H6'), 1.28 (2H, m, H-7', H-4'), 1.30 (3H, s, H-7'”), 1.31 $(3 \mathrm{H}, \mathrm{s}, \mathrm{H}-18), 1.33(3 \mathrm{H}, \mathrm{d}, J=8.0 \mathrm{~Hz}, \mathrm{H}-6 "), 1.50$ (1H, m, H-14), 1.59 (1H, dd, J=6.3, 7.8 Hz, H-2”), $1.65\left(1 \mathrm{H}, \mathrm{m}, \mathrm{H}-4^{\prime}\right), 1.79(1 \mathrm{H}, \mathrm{d}, J=10.0 \mathrm{~Hz}, \mathrm{H}-7)$, $1.89(1 \mathrm{H}, \mathrm{m}, \mathrm{H}-14), 2.02(1 \mathrm{H}, \mathrm{d}, J=8.3 \mathrm{~Hz}, \mathrm{H}-9), 2.16$
(2H, m, H-4, H-8), 2.30 (1H, d, J=9.6 Hz, C-4' '-OH), 2.32 (6H, s, H-7'/H-8'), 2.37 (3H, s, H-3), $2.55(1 \mathrm{H}$, d, J=5.0 Hz, H-2'), $2.68(1 \mathrm{H}, \mathrm{s}, \mathrm{H}-3$ '), $2.70(1 \mathrm{H}, \mathrm{d}$, $J=8.7 \mathrm{~Hz}, \mathrm{H}-9), 3.00(1 \mathrm{H}, \mathrm{q}, \mathrm{H}-10), 3.07$ (1H, s, H-2), $3.05(1 \mathrm{H}, \mathrm{s}, \mathrm{C}-6-\mathrm{OH}), 3.07(1 \mathrm{H}, \mathrm{s}, \mathrm{H}-4$ '), $3.24(1 \mathrm{H}$, dd, $J=10.1,7.6 \mathrm{~Hz}, \mathrm{H}-2$ '), 3.34 (3H, s, H-8'), 3.36 $(1 \mathrm{H}, \mathrm{s}, \mathrm{C}-12-\mathrm{OH}), 3.55(1 \mathrm{H}, \mathrm{m}, \mathrm{H}-5$ '-H), $3.67(1 \mathrm{H}, \mathrm{d}$, $J=8.0 \mathrm{~Hz}, \mathrm{H}-5), 3.70(1 \mathrm{H}, \mathrm{d}, J=9.2 \mathrm{~Hz}, \mathrm{H}-11), 4.07$ $(1 \mathrm{H}, \mathrm{dq}, \mathrm{H}-5$ '), $4.25(1 \mathrm{H}, \mathrm{dd}, J=8.1,2.0 \mathrm{~Hz}, \mathrm{H}-3)$, $4.44(1 \mathrm{H}, \mathrm{d}, J=6.8 \mathrm{~Hz}, \mathrm{H}-1$ ') $4.69(1 \mathrm{H}, \mathrm{t}, J=6.9 \mathrm{~Hz}$, $\mathrm{H}-13), 5.16(1 \mathrm{H}, \mathrm{d}, J=5.1 \mathrm{~Hz}, \mathrm{C}-11-\mathrm{OH}), 5.17(1 \mathrm{H}, \mathrm{d}$, $J=6.2 \mathrm{~Hz}, \mathrm{H}-1$ ”), 9.65 (1H, s, C-6-OH).

${ }^{13} \mathrm{C} N M R$ spectral data of sample $1(100 \mathrm{MHz}$, $\left.C D C l_{3}\right): \delta(\mathrm{ppm}) 7.3$ (C-21), 9.1 (C-17), 11.3 (C-15), 14.6 (C-16), 16.3 (C-22), 18.2 (C-6”), 21.3 (C-14), 21.6 (C-6'), 21.8 (C-19), 22.0 (C-7”), 26.8 (C-8), 27.6 (C-18), 28.1 (C-4'), 34.7 (C-20), 36.3 (C-2”), 40.5 (C-7'), 40.5 (C-8'), 42.4 (C-4), 42.5 (C-7), 45.4 (C-2), 49.5 (C-8”), 62.7 (C-10), 65.7 (C-5”), 65.9 (C3'), 68.6 (C-5'), 70.6 (C-9), 70.8 (C-2'), 73.1 (C-3”), 73.7 (C-11), 73.9 (C-12), 74.2 (C-6), 77.5 (C-13), 77.7 (C-3), 78.1 (C-4”), 83.4 (C-5), 94.5 (C-1”), 103.0 (C-1'), 179.0 (C-1).

The ${ }^{1} \mathrm{H}$ and ${ }^{13} \mathrm{C}$ NMR spectral data of the first sample were compared with those of standard azithromycin and reported values, and found identical. This observation leads to the conclusion that the qualitative determination of antibiotic tablets can be carried out by ${ }^{1} \mathrm{H}$ and ${ }^{13} \mathrm{C}$ NMR experiments.

\section{Conclusion}

The present study evaluates the quality of azithromycin available in the market samples along with the standard azithromycin by physical, chromatographic (HPLC) and spectroscopic $\left({ }^{1} \mathrm{H}\right.$ and ${ }^{13} \mathrm{C}-\mathrm{NMR}$ ) studies. The range of weight variation was $0.10-1.78 \%$ which is well below the allowed limit of 5\%. The FT-IR spectra displayed several characteristic bands, with two prominent absorptions at 1723 and $1187 \mathrm{~cm}^{-1}$ for $\mathrm{C}=\mathrm{O}$ group and $\mathrm{C}-\mathrm{O}$, respectively. HPLC analysis gave reproducible results for the standard and test samples. The ${ }^{1} \mathrm{H}$ - and ${ }^{13} \mathrm{C}$-NMR spectral data of standard azithromycin and 
test samples were found to be identical which led to the conclusion that ${ }^{1} \mathrm{H}$ - and ${ }^{13} \mathrm{C}$-NMR experiments are feasible tools for qualitative determination of azithromycin in tablets.

\section{Acknowledgements}

The authors are grateful to International Science Programme (ISP), Uppsala University, Sweden for financial supports.

\section{References}

Al-Rimawi, F. and Kharoaf, M. 2010. Analysis of azithromycin and its related compounds by RP-HPLC with UV dtection. J. Chrom. Sci. 48, 86-90, DOI: 10.1093/chromsci/48.2.86.

Alapi, E.M. and Fischer, J. 2006. Table of Selected Analogue Classes. In Fischer J, Ganellin CR (Eds.). Analogue-based Drug Discovery. Weinheim: Wiley-Vch Verlag GmbH \& Co. KGaA. p. 498, ISBN 978-3-527-31257-3.

Azithromycin. 2015. The American Society of HealthSystem Pharmacists. Archived from the original on 5 September 2015. Retrieved 1 August 2015.

Azithromycin International Brands, 2017. Drugs com. Archived from the original on 28 February 2017. Retrieved 27 February 2017.

Bekele, L.K. and Gebeyehu, G.G. 2012. Application of Different Analytical Techniques and Microbiological Assays for the Analysis of Macrolide Antibiotics from Pharmaceutical Dosage Forms and Biological Matrices. Int. Scholarly Research Network (ISRN), Analytical Chemistry Volume 2012, Article ID 859473, 17 pages doi:10.5402/2012/859473.

British Pharmacopeia 2011. Appendix XII C. Consistency of Formulated Preparations. Volume V.

Essential Medicines, 2017. World Health Organization. Retrieved 19 January 2017.

Firth, A. and Prathapan, P. 2020. Azithromycin. The first broad-spectrum therapeutic. Eur. J. Med. Chem. 207, 112739. doi:10.1016/j.ejmech.2020.112739.

FDA, February 2016. US azithromycin label. Archived from the original on 23 November 2016.

Gautret, P., Lagier, J-C., Parola, P., Hoang, V.T., Meddeb, L., Mailhe, M., Doudier, B., Courjon, J., Giordanengo, V., Vieira, V.E., Dupont, H.T., Honoré, S., Colson, P., Chabrière, E., Scola, B.L., Rolain, JM., Brouqui, P. and Raoult, D. 2020. Hydroxychloroquine and azithromycin as a treatment of COVID-19: results of an open-label non-randomized clinical trial. Int. J. Antimicrob. Agents. 56, 105949. doi:10.1016/j.ijantimicag.2020. 105949
David, G. 2008. Antimicrobial Drugs: Chronicle of a Twentieth Century Medical Triumph (1.publ.ed.) Oxford University Press, Oxford, p. 239, ISBN 9780199534845, Archived from the original on 5 March 2016.

Gendrin, C., Roggo, Y. and Collet, C. 2008. Pharmaceutical applications of vibrational chemical imaging and chemometrics: a review. J. Pharm. Biomed. Anal. 48, 533-553, doi:10.1016/j.jpba.2008. 08.014 .

Godfrey, S., Bbosa, Mwebaza, N., Odda, J., David, B., Kyegombe, and Ntale, M. 2014. Antibiotics/ antibacterial drug use, their marketing and promotion during the post antibiotic golden age and their role in emergence of bacterial resistance. Article in Health, 6 , 410-425 doi.org/10.4236/health.2014.65059.

Jayanna, B. K., Nagendrappa, G., Arunkumar and Gowda, N. 2012. Spectrophotometric estimation of azithromycin in tablets. Ind. J. Pharm. Sci. 74, 365367.

Ji, X.D., Wen, B.Z., Yan, C.F., Dan, Q.S. and Chang, Q.H. 2011. Quantitative calibration models for the determination of azithromycin and decladinosylazithromycin in azithromycin injection powders using diffuse reflectance near infrared spectroscopy. J Near Infrared Spectrosc, 19, 265-275.

Jumaa, S. and Karama, R. 2015. Antibiotics. Chapter 2, Nova Science Publishers, Inc. 4804, pp. 41-73, ISBN: 978-1-63463-828-9, DOI: 10.13140/RG.2.1.5114.

Li, Y., Du, D., Cai, W. and Shao, X. 2011. Classification and quantitative analysis of azithromycin tablets by Raman spectroscopy and chemometrics. Am. J. Analyt. Chem. 2, 135-141, doi:10.4236/ajac.2011.22015, http://www.SciRP.org/journal/ajac.

McCreary, E.K. and Pogue, J.M. 2020. Coronavirus disease 2019 treatment: a review of early and emerging options. Open Forum Infectious Diseases, 7, ofaa105, doi:10.1093/ofid/ofaa105

Rang, H. P., Dale, M. M., Ritter, J. M. and Moore, P. K. 2003. Pharmacology, Elsevier, 5th edition.

Trigathi, K. D. 2003. Essentials of Medical Pharmacology. Jaypee Brothers (5th edition), Medical Publishers, New Delhi, India.

Scafi, S. H. F. and Pasquini, C. 2001. Identification of counterfeit drugs using near-infrared spectroscopy. Analyst, 126, 2218-2224, doi:10.1039/b106744n.

Sengupta, S. 1988. Statistical evaluation of Pharmacopoeia. Weight variation tests for tablets using a ratio statistics. Appl. Statistics, 37, 396. doi:10. 2307/2347313. 
Shaikh, K.A., Patil, S.D. and Devkhile, A.B. 2008. Development and validation of a reversed-phase HPLC method for simultaneous estimation of ambroxol hydrochloride and azithromycin in tablet dosage form. J. Pharm. Biomed. Anal. 48, 1481-1484.

WHO, 2019. World Health Organization Model List of Essential Medicines: 21st list 2019. Geneva: World Health Organization. hdl:10665/325771. WHO/MVP/ EMP/IAU/2019.06. License: CC BY-NC-SA 3.0 IGO.

WHO, 2018. Critically important antimicrobials for human medicine (6th revision ed.). Geneva: World Health Organization. hdl:10665/312266. ISBN 97892415155 28. License: CC BY-NC-SA 3.0 IGO.
Yang, Z.Y., Wang, L. and Tang, X. 2009. Determination of azithromycin by ion-pair HPLC with UV detection. $J$. Pharm. Biomed. Anal. 49, 811-815.

Zubata, P., Ceresole, R., Rosasco, M. A. and Pizzorno, M. T. 2002. A new HPLC method for azithromycin quantitation. J. Pharm. Biomed. Anal. 27, 833-836. 